\title{
THE ULAMA IN INDONESIA: Between Religious Authority and Symbolic Power
}

\author{
Zulkifli \\ Fakultas Ilmu Sosial dan Ilmu Politik UIN Syarif Hidayatullah \\ Jl. Ir. H. Juanda No. 95, Ciputat, Jakarta, 15419 \\ e-mail: zul_harmi@yahoo.com
}

\begin{abstract}
Abstrak: Ulama di Indonesia: Antara Otoritas Keagamaan dan Kekuatan Simbolik. Artikel ini berupaya menguji hubungan antara peranan ulama, otoritas keagamaan, dan kekuatan simbolik dalam masyarakat Muslim Indonesia dengan meneliti sejumlah literatur penting. Dalam studi ini penulis menggunakan kerangka teoretis ahli sosiologi Prancis Pierre Bourdieu, yakni teori praksis yang hampir tidak pernah digunakan dalam kajian agama di Indonesia. Studi ini mengungkapkan bahwa ulama memegang peranan yang strategis dalam masyarakat Indonesia dan peranannya tetap penting dalam konteks perubahan sosial, politik, dan ekonomi yang cepat. Tetapi otoritas keagamaan ulama telah terfragmentasi sejak lama dan media global dan teknologi informasi telah membuat otoritas tersebut semakin plural. Dalam konteks ini otoritas keagamaan merupakan arena yang kompetitif di mana kelompok tradisionalis, reformis, radikalis, dan pendatang baru berkompetisi untuk mencapai pengakuan. Studi ini juga menegaskan bahwa otoritas keagamaan dan pengakuan berjalan hanya dengan adanya kekuatan simbolik.
\end{abstract}

\begin{abstract}
This article attempts to examine the relationship between the role of ulama, religious authority, and symbolic power in Indonesian Muslim society by scrutinizing famous literature of ulama in Indonesia. In the study I utilize French sociologist Pierre Bourdieu's theoretical framework known as theory of practice, hardly ever used in the study of religion (Islam) in Indonesia. The study reveals that the ulama have played a strategic role in the Indonesian society and their role continues to be important in the context of rapid social, political, and economic changes. However, the religious authority of ulama has been fragmented and the global media and information technologies have made the authority more pluralized. The religious authority is a competitive field in which traditionalist, reformist, radicalist, and new entrants compete for gaining recognition. The study also affirms that the religious authority and recognition are exercised only by the symbolic power.
\end{abstract}

Keywords: religious authority, ulama, symbolic power, Indonesia 


\section{Introduction}

The Indonesian term ulama is used to denote both religious scholars who have thorough knowledge of Islam and socio-religious leaders who occupy important and strategic position. The ulama, namely "men of religious learning and prestige"1 play important social, political, cultural, and religious roles in the history and development of Muslim society in Indonesia. In the history, the ulama have led their community to fight against colonial authorities so that they could free the country from colonialism and Indonesia obtained its independence on August 17, 1945. In the independence era the country still owed the role of the ulama in succeeding its development programs in various fields such as education, social, politics, economy, religion, and culture. Even there is no single development program without support from ulama. Here, we witness the diverse roles of ulama, going beyond the traditional domain of religious sphere in rural areas.

Questions may arise when the position and role of ulama are faced with the rapid change in society, namely when the Muslim society experiences modernization and globalization. Indonesia has witnessed the advance of mass higher education and the rising use of print and electronic media which contribute to the rise of the Islamic public sphere in which the dominant role of ulama in religious discourse may end. In other words, modernization and globalization may challenge the authority of ulama. On the impact of media on the Muslim world, Eickelman and Anderson point out that the transmission and circulation of Islamic texts through a variety of media “... mark a fragmentation of authority ... [and] set aside the long tradition of authoritative discourse by religious scholars in favour of direct understanding of texts." ${ }^{2}$ Further, the circulation of Islamic texts among members of Muslim community has expanded the number and scope of its audience. "The spread of literacy and the translation of formerly esoteric texts have terminated the monopoly of the ulama in any religious discourse. Literacy and the growing importance of the print culture have expanded the number of people who can directly conduct a dialogue with the text." ${ }^{3}$ Furthermore, Turner writes: "Global information technologies and their associated cultures undermine traditional forms of religious authority because they expand conventional modes of communication, open up new opportunities for debate and create alternative visions of the global community."4

${ }^{1}$ Stephen Humphreys, Islamic History: A Framework for Inquiry (London: I.B. Thauris, 1999), p. 187.

${ }^{2}$ Dale Euckelman dan J.W. Anderson, "Print, Islam, and the Prospect for Civic Pluralism: The New Religious Writings and Their Audiences," in Journal of Islamic Studies, Vol. VIII, No.1, 1997, p. 49.

${ }^{3}$ Taufik Abdullah, "The Formation of a New Paradigm? A Sketch on Contemporary Islamic Discourse," in Mark Woodward (ed.), Toward a New Paradigm: Recent Developments in Indonesia Islamic Thought (Tempe: Arizona University Program for Southeast Asia Studies, 1996), p. 75.

${ }^{4}$ Bryan S. Turner, "Religious Authority and the New Media," in Theory, Culture, and Society, Vol. XXIV, No. 2, 2007, p. 120. 
This paper is aimed at examining the position and role of ulama in the contemporary Indonesian society with change, modernization, and globalization that challenge their religious authority. The study attempts to examine the relationship between the role of ulama, religious authority, and symbolic power in Indonesian Muslim society. But this paper begins by reviewing the important previous studies on the role of Indonesian ulama.

\section{The Role of Ulama}

There have been so far many historical, sociological, and anthropological studies on the role of Indonesian ulama. The studies in general regard the ulama as an elite who plays an essential role in society. Examining the ulama (kiai) in Java, Geertz considers them as cultural brokers who mediate the national system and local community but the role may obsolete with the rise of information and communication technologies. ${ }^{5}$ Then, in 1976, Horikoshi wrote her $\mathrm{PhD}$ thesis on Sundanese ulama in West Java that commonly called ajengan. Horikoshi is the first scholar who focused a detailed study on the ulama and their relation to social change in Sundanese society. Criticizing Geertz's concept of cultural broker, Horikoshi maintains that the ulama in West Java cannot be identified as brokers or mediators between the local community and the national system and therefore their role will not be obsolete. The ulama not only filter information that they consider important and appropriate to the local community but also "block channels of communication and forces of change and withhold information in order to prevent the development of direct ties between the two ends, and avoid jeopardizing their own oppositions." ${ }^{6}$ The ulama instead become active agent of social change and transformation. Therefore, the ulama are able to preserve their independent position economically and socio-culturally. In Horikoshi's point of view, it is the quality of charisma that can make the ulama able to preserve their position in society.

Another important study was conducted by Dhofier on the pesantren tradition. He focused his attention on the role of kiai in the maintenance of Islamic ideology in Javanese society. He suggests that the kiai have developed particular mechanism, namely ideological, kinship and religio-political, in order to pursue their unity and tradition. ${ }^{7}$ His focus on pesantren, however, led him to neglect the pesantren as an element of social system which is related to, influenced by, and influences other elements of social system. As a consequence, the complex relation of pesantren to outside world is not clearly examined. In this regard, Dirdjosanjoto criticizes that Dhofier's emphasis on the functions of pesantren results in

${ }^{5}$ Clifford Geertz, "The Javanese Kijai: The Changing Role of a Cultural Broker," in Comparative Studies in Society and History, No. 2, 1959-1960, p. 200-249.

${ }^{6}$ Hiroko Horikoshi, Kiai dan Perubahan Sosial, transl. Umar Basalim and Andi Muarly Sanrawa (Jakarta: P3M, 1987), p. 5-6.

7Zamakhsyari Dhofier, Tradisi Pesantren: Studi tentang Pandangan Hidup Kyai (Jakarta: LP3ES, 1982). 
the static and monolithic description of the socio-religious and educational institution. ${ }^{8}$ Nevertheless, Dhofier has made great contribution to studies of traditional Islam in Indonesia, particularly in his uncovering the complex networks that have been established by the kiai in order to maintain the pesantren tradition.

In addition, in his study of Islam in Madura, East Java, Mansurnoor attempts to uncover the complex relationships between the ulama and villagers and between the ulama and the national system to shift and find accommodation in response to change. He sees the ulama in Madurese society as an inseparable element of the local social structure and maintains that the ulama occupy strategic position and play an important role in a number of domains. As religious leaders the ulama have nurtured the emergence of complex networks of followers and colleagues which have sustained the stability of the leadership role in facing social and political change in Madura. ${ }^{9}$

Still on the ulama in East Java, Turmudi completed his study in 1996, focusing on the changing leadership roles of the kiai. Turmudi observes this phenomenon in a variety of pesantren in Jombang, East Java. Turmudi concludes that the changing leadership roles of the kiai result from the changing in pesantren education and society at large. There took place a so-called the profanization of charisma that led to reducing of the kiai influence in society. But the changing leadership roles of the kiai as a result of social change took place gradually since social change did take place gradually. ${ }^{10}$

Then, Dirdjosanjoto analyzes the role of ulama in social and political changes in Muria, Central Java. Criticizing Dhofier's static and monolithic description of the pesantren tradition, Dirdjosanjoto distinguishes the kiai pesantren (major ulama) from the kiai langgar (minor ulama). With regard to theoretical framework, he attempts to compromise the two different roles of ulama, namely as a cultural broker suggested by Geertz and as a political entrepreneur suggested by Horikoshi. He maintains that the ulama can be regarded as both cultural broker and political entrepreneur. But he emphasizes that the ulama's position as a cultural broker is not restricted only in time of transition and in mediating local and national cultures but it operates in much broader context. In addition, the ulama occupy an intersectional position between the profane and the religious and are expected to interpret the relations between the two worlds for the villagers. Dirdjosanjoto also stresses that the ulama's role as a mediator in all aspects of human life, namely between religious doctrines and practices, between God and society, and between the universal Islamic civilization and local Islamic tradition is the fundamental key to the ulama's authority in the eyes of Muslim society. The ulama's success, according to Dirdjosanjoto, is due to their dual roles,

${ }^{8}$ Pradjarta Dirdjosanjoto, Memelihara Umat: Kiai Pesantren dan Kiai Langgar (Yogyakarta: LKiS, 1999), p. 25.

${ }^{9}$ Iik Arifin Mansurnoor, "Ulama, Villagers, and Change: Islam in Central Madura" (Ph.D Dissertation, McGill University, 1987).

${ }^{10}$ Endang Turmudi, Perselingkuhan Kiai dan Kekuasaan (Yogyakarta: LKiS, 2003). 
both as a religious and political leader, which are always maintained. But he still separates both roles and even tends to emphasize the political aspect of ulama rather than their religious aspect. Thus, the complex religious world of ulama itself is still unclearly explained in his study.

In addition to the above sociological and anthropological accounts, two important historical studies should be mentioned. First is Azra's account of Middle Eastern and Malay-Indonesian networks of ulama in the $17^{\text {th }}$ and $18^{\text {th }}$ centuries. This pioneering study uncovers the international networks of ulama centered in Mecca and Medina in which hadith isnad and thariqah silsilah became two important vehicles that made the linkages of the networks relatively solid and in turn contributed to a general tendency toward Islamic reformism both in the Middle East and Southeast Asia. The networks proved to be one of the most important learning grounds for the Southeast Asian (Jawi) students whe came the Haramayn since the early seventeenth century to pursue Islamic learning. "Through the networks, the Jawi students received not only various branches of the Islamic learning, but also the renewed spirit of Islamic renewal. It is not surprising, that when they returned to the Malay-Indonesian world, these Jawi students became the prominent figures in the Islamic renewal movements in Southeast Asia."12

The other account by Burhanudin (2007) who intends to enhance the above-mentioned Azra's study by discussing the intellectual networks of ulama, their socio-political experiences, their encountering of challenges, and their Islamic ideas and practices during the colonial period. Using the intellectual history method, Burhanudin avoids taking a static picture of ulama while attempting "to emphasize the constant changing voices and configurations of Islam the ulama have discussed in Indonesian history." 13 Although focusing on the colonial era, he begins to trace the authority of ulama since the pre-colonial Islamic kingdoms of the archipelago when they occupied the position of qadi and syaikh al-Islam in strengthening the Islamic performance in the kingdoms. With the fall of the kingdoms alongside Western occupation, the ulama established their own Islamic learning institutions namely pesantren in Java, surau in Minangkabau, and dayah in Aceh outside the kingdom domain. The Islamic learning institutions became their own institutional foundation for formulating Islam and creating religious authority. Then, the ulama appeared to the sole experts of Islam for their community. This even became stronger with the intensified networks with Middle Eastern ulama. The ulama still had a strong foundation with their Islamic learning institutions and santri community although the colonial policy created

${ }^{11}$ Azyumardi Azra, Jaringan Ulama Timur Tengah dan Kepulauan Nusantara Abad XVII dan XVIII (Bandung: Mizan, 1994).

${ }^{12}$ Azyumardi Azra, Islam in the Indonesian World: An Account of Institutional Formation (Bandung: Mizan, 2006), p. 243.

${ }^{13}$ Jajat Burhanudin, "Islamic Knowledge, Authority, and Political Power: The Ulama in Colonial Indonesia" (Ph.D Thesis, Leiden University, 2007), p. 7. 
the colonized religious elite, the penghulu, and the rise of Islamic modernism from Cairo, Egypt. In encountering changes and modernity in the East Indies, the ulama attempted to formulate a so-called traditional Islam while modernizing the Islamic learning institutions as the basic pillars of their existence. Finally, in his reflection, Burhanudin provides us with the latest statistical data by which he maintains "to include the ulama as one of the major contributory factors in the making of Indonesia in the future." ${ }^{14}$ This is a very important point even though it is beyond the focus of his study and far beyond its period.

In addition, there many studies on the ulama in the local community in Indonesia, published or unpublished, but there is no place here to review them. It suffices it to say that despite numerous studies of ulama in Indonesia, none is useful to explain satisfactorily the role of ulama in the context of rapid political, social, economic changes in the Indonesian society.

\section{The Authority of Ulama}

The analysis of religious authority cannot be done without considering Max Weber's classical categories of authority, namely rational, traditional, and charismatic. The authority of ulama is very close to the charismatic authority. In accordance with Weber's view, religious authority may be defined as "a certain quality of an individual personality by virtue of which he is set apart from ordinary men and treated as endowed with supernatural, superhuman, or at least specifically exceptional qualities."15 The concept of authority should not be confused with the concept of power. Power may be defined as the capacity to act freely in responding resistances from individuals or groups while authority is the right to act, lead or decide. While power is not institutionalized and always related to resistance and confrontation, authority is institutionalized and represents a set of norms, procedures, and traditions to be implemented in a social unit. ${ }^{16}$ Although in his above-mentioned study Burhanudin intends to examine the authority of ulama under the political power of colonial government, his analysis includes the religious power of ulama in establishing and maintaining their authority because authority will not run without power. "Power is one way of gaining compliance with the decisions made by those who are in positions of authority." 17 We will analyze this later in the next section in the concept of symbolic power.

With regard to religious authority in Indonesia, like in other Muslim communities in the world, we should bear in mind that there is no single religious authority that is recognized

${ }^{14} I b i d$, p. 259.

${ }^{15}$ Max Weber, Theory of Social and Economic Organization, transl. Henderson and Talcott Parsons (Glancoe-Ill: The Free Press, 1957), p. 329.

${ }^{16}$ Elmer S. Miller and Charles A. Weitz, Introduction to Anthropology (Eaglewood Cliffs: Prentice-Hall Inc, 1979), p. 530.

${ }^{17} I b i d$, p. 531. 
and binds all segments of the Muslim community in the country. Religious authority is indeed pluralized. This is because religious authority in Islam is based on recognition and support. "A religious leader in Islam is one who has achieved considerable recognition and support, and as, a consequence, religious leaders in Islam tend to proliferate and have to engage in disputes about their authority and their ability to issue a fatwa or legal judgment."18

Since its early history, Indonesian Islam has been marked by the fragmentation of religious authority. It is true that the Muslim community recognizes the governmentsponsored ulama council of Indonesia, Majlis Ulama Indonesia (MUI) established in July 1975. It functions to facilitate two-way communication between the government's interest and the Muslim community. MUI should represent all fractions among the Indonesian Muslims: the traditionalist NU, the modernist Muhammadiyah, and others. ${ }^{19}$ But during the New Order era MUI was under the great influence of the New Order government and this is indicated by most of the fatwa of MUI that were made to give Islamic justification for government policies. Since the reformation era it shifted from being state-oriented to being umma-oriented even though the word umma is just a slogan without real evident since it appeared to gravitate the radical wing of Islamic movements with the support of the then general secretary and now vice chairman Din Syamsuddin. MUI membership has included the exponents of radical Islam such as Majlis Mujahidin Indonesia (MMI), Front Pembela Islam (FPI), and Hizbut Tahrir Indonesia (HTI). ${ }^{20}$

Besides MUI, Nahdlatul Ulama (NU) is the traditional religious authority. "Traditionalists have two defining characteristics; they seek to preserve the authority of medieval Islamic scholarship, and they tend to be more tolerant of local customs." ${ }^{21}$ The traditionalist Muslims believe and follow the doctrines, norms, and traditions of NU which are strongly based on medieval ulama. The concept of taqlid ${ }^{22}$ for the laity is important in order to prevent them from going astray. The teachings are formulated under the term ahl al-sunnah wa aljama'ah (abbreviated Aswaja) in which the ulama attempt to maintain the long-established religious doctrines and practices and thus create their religious authority. This traditional religious authority has strong foundation in such Islamic learning institutions as pesantren, surau, and dayah. With the intensified connections with the Middle East many santri pursued their Islamic learning in the Middle East, particularly Mecca and Medina, because it was considered as "the best way to achieve high qualifications in Islamic studies." ${ }^{23}$ They

${ }^{18}$ Turner, "Religious Authority," p. 119.

${ }^{19} \mathrm{M}$. Atho Mudzhar, Fatwa of the Council of Indonesian Ulama: A Study of Islamic Legal Thought in Indonesia 1975-1988 (Jakarta: INIS, 1993), p. 47-48.

${ }^{20}$ Burhanudin, "Islamic Knowledge," p. 255.

${ }^{21}$ Greg Felly and Virginia Hooker, Voices of Islam in Southeast Asia; A Contemporary Sourcebook (Singapore: ISEAS, 2006), p. 40.

${ }^{22}$ Emulating, following, imitating the sayings of mujtahid (those who have the authority to formulate legal opinions from the principle sources of Islam) or previous generation of ulama.

${ }^{23} Y u d i$ Latif, Indonesian Muslim Intelligentsia and Power (Singapore: ISEAS, 2008), p. 69. 
then became the ulama upon their return to homelands, establishing Islamic learning institutions, being engaged in preaching and teaching, the traditional authority was strengthened. Throughout history the ulama continue to strive for defending the traditional religious authority in the modernized life of the community in responding to modernity and Islamic reformism.

The reformist or modernist Muslims also have their own religious authority, Muhammadiyah being the most important one. They are attached with the reformist brand of Islam that promotes the new approaches to Islam in response to the contemporary demand of modernity, particularly the call to return to the principle sources of Islam, the Quran and Sunnah, and the reopening the gate of ijtihad (independent interpretation of Islamic doctrines based on the sufficient knowledge of the Quran and Sunnah). The reformists "regard the theology and ritual practices of the traditionalists as impure and a deviation from the original teachings of Islam." ${ }^{24}$ This Islamic reformation is against the longestablished traditional Islamic ideas and practices and therefore challenges the traditional authority of ulama. The reformist ulama urge Muslims not merely to base their religious interpretation on the opinion of ulama without further examining it through the Quran and hadith. The challenge to the traditional religious authority was disseminated through schools and printing presses..$^{25}$ Competition and even conflict, besides cooperation, have marked the relations between these two forms of religious authority in Indonesia.

Now, the radical or salafi brand of Islam also has its strong foundation among the small minority of the Muslim society. It grew since 1970s and rose with the fall of the New Order in 1998 known as the reformation era. Under the spirit of Islamic reformation, this brand attempts to impose the Islamic doctrines on the regulation of Indonesian state and society.

Radical Islam refers to those Islamic movements that seek dramatic change in society and the state. The comprehensive implementation of Islamic law and the upholding of 'Islamic norms', however defined, are central elements in the thinking of most radical groups. Radical Muslims tend to have a literal interpretation of the Qur'an, especially those sections relating to social relations, religious behavior and the punishment of crimes, and they also seek to adhere closely to the perceived normative model based on the example of the Prophet Muhammad (the Sunnah). ${ }^{26}$

The radical Islamic movements include Laskar Jihad, Front Pembela Islam (FPI), Majlis Mujahidin Indonesia (MMI), and Partai Keadilan Sejahtera (PKS). The implementation of shariah in the socio-political sphere of Indonesia has become the main agenda of these radical movements. To be added to these is a transnational Islamic movement Hizbut

\footnotetext{
${ }^{24}$ Fealy and Hooker, The Voices of Islam, p. 40.

${ }^{25}$ Burhanudin, "Islamic Knowledge," p. 193.

${ }^{26}$ Fealy and Hooker, The Voices of Islam, p. 4.
} 
Tahrir Indonesia (HTI) that tries to strive for the establishment of caliphate system in the social, economic and political fields of Muslim world. Like their counterparts, these movements disseminate their ideas and teachings through pesantren, school, and mass media. The leaders of the movements are also called and recognized as ulama claiming their holding of religious authority on their followers. With their skills in using media, disseminating, and inculcating their ideas and teachings, the influence of this radical brand tends to strengthen among certain segments of the Indonesian Muslim society.

In addition, the religious authority may be differentiated between ulama and Sufi. In Indonesia, like in other parts of the world, we find a number of reformist ulama who are strongly oriented to fiqh while rejecting the practicing of Sufism because they see Sufism as teachings added to Islam from outside. For Sufis, it is strongly based on the Quran and Sunnah. This has become an influential model of Muslim society which contrasts the Islam of the saints with the scripturalist Islam of the ulama. Sufi Islam is cast as hierarchical and the Islam of the ulama as more egalitarian. ${ }^{27}$ Frequently, scholars distinguish ulama who maintain shariah from Sufis who practice Sufism while discarding shariah. Nicolson, for instance, suggests: "Many walis, however, regard the law as a curb that is indeed necessary so long as one remains in the disciplinary stage, but may be discarded by the saints. Such a ous condemned for actions which outwardly seem irreligious." ${ }^{28}$ For Sufis, this is certainly not correct. They claim to follow the famous doctrine, that is, whoever learns jurisprudence and neglects Sufism becomes reprobate; whoever learns Sufism and neglects jurisprudence becomes an apostate, and whoever combines both attains the realization of the Truth. ${ }^{29}$ However, the authority and legitimacy of Sufism continue to be questioned and criticized by a certain number of ulama.

Furthermore, with global media and information technologies, religious authority has become more pluralized. While the mentioned groups use them for their own purposes, among others, of maintaining their authority, they create the new form of authority which is neither charismatic due to no charisma influencing the web nor legal-rational because it is not the product of hierarchical organization of offices issuing fatwa. This may be called the virtual authority of the Internet which is devolved, dispersed and dissipated. ${ }^{30}$ However, "traditional forms of authority continue to dominate local communities in Islam, where memorization and recitation continue to play a central role in religious revivalism and in sustaining the cohesion of local communities." 31

From the above description, we uncover that religion (Islam) has become a competitive

\footnotetext{
${ }^{27}$ Ernest Gellner, Muslim Society (Cambridge: Cambridge University Press, 1983).

${ }^{28}$ R.A Nicholson, The Mystic of Islam (London: Routledge and Kegan Paul lit., 1975), p. 127.

${ }^{29}$ K.H. Syansuri Badawi, "Tarekat, Suatu Keniscayaan” in Pesantren Vol. II No. 3, 1985, p. 39.

${ }^{30}$ Turner, "Religious Authority," p. 124.

${ }^{31}$ Ibid.
} 
field in which each group of the ulama strive for establishing and gaining their religious authority.

A field may be defined as a network, or a configuration, of objective relations between positions. These positions are objectively defined, in their existence and in the determinations they impose upon their occupants, agents or institutions, by their present and potential situation (situs) in the structure of the distribution of a species of power (or capital) whose possession commands access to the specific profits that are at stake in the field, as well as by their objective relations to other positions (domination, homology, etc.). ${ }^{32}$

According to Bourdieu, the religious field is a competitive arena of relations in which each group struggle over the production, acquisition, and control of forms of religious capital, material and symbolic resources, that is, the authority to administer goods of salvation and exercise legitimate power over the laity. ${ }^{33}$ Religious field in Indonesia has become an arena of competition, at least, among the traditional, the reformist, and the radical religious authorities. Although the MUI has tried to accommodate all demands of the religious groups, the council itself has been the subject of competition among them in order to exert its own influence. As mentioned above, the primary competitors in the struggle for religious authority in Indonesia are the ulama of each group.

\section{The Recognition and Symbolic Power}

Our analysis of the recognition of ulama's religious authority and symbolic power may begin by showing the recent national surveys on Islam and democracy conducted by Pusat Pengkajian Islam dan Masyarakat (PPIM) UIN Jakarta in 2004 and 2006. The surveys strongly prove the important standing of ulama. The survey of 2004 shows that $44.6 \%$ and $42.6 \%$ of the respondents (from 1.880 Muslim respondents from nearly entire country) stated that they quite often and sometimes go to ask the ulama for religious guidance respectively. Only $12.8 \%$ stated that they never go to meet the ulama for the same purpose. The tendency increased in the survey of 2006 with 850 Muslim respondents, that is, they stated quite often (63.9\%), sometimes (32.3\%), and never (3.9\%) go to see the ulama for religious guidance. ${ }^{34}$

Another element of the surveys also proves the strategic position and role of the ulama in the Muslim society. From the 2004 survey, we find $66.2 \%$ of respondents request religious affairs while about $40 \%$ about the socio-political issues. In addition, in the surveys of 2004

\footnotetext{
${ }^{32}$ Pierre Bourdieu and Loic j.D. Wacquant, An Invitation to Reflexive Sociology (Chicago: Chicago University Press, 1992), p. 24.

${ }^{33}$ Pierre Bourdieu, "Genesis and Structure of the Religious Field," in Comparative Social Research No. 13, 1990, p. 22.

${ }^{34}$ Burhanudin, "Islamic Knowledge," p. 257-258.
} 
and 2006, it appears that most respondents (78.6\% and $81.6 \%$ respectively) stated that they gave trust to the ulama. ${ }^{35}$

The above statistical data indicate the general recognition of the authority of ulama among the Indonesian Muslims in the field of religion. We should bear in mind, however, that the MUI's recommendation of 1999 to the Indonesian Muslim in order not to vote for Partai Demokrasi Indonesia Perjuangan (PDIP) led by Megawati Sukarno Puteri was neglected in the general election of 1999. In fact, the PDIP won the general election with $33.73 \%$ of the total vote and $33.12 \%$ of total seats. ${ }^{36}$ This may indicate the non-recognition of the authority of MUI in terms of general election. If we have to compromise the contradictory data, we would suggest the Muslim trust to the ulama only in religious affairs instead of political affairs. But it is advisable to suggest that the MUI does not have symbolic power over the Muslim society regarding political affairs.

Additionally, although the religious authority of ulama is generally recognized by the majority of the Indonesian Muslim, the affiliation of Muslims to the type of ulama holding the authority remains silent from the data since, as affirmed above, there is no single religious authority in the country. Certain Muslim groups only recognize their own ulama who hold the legitimate religious authority while others do theirs. In other words, the religious authority as well as recognition in Indonesia is fragmented.

The recognition is closely related to the competitive religious field and the concept of orthodoxy. The recognition is to be gained, competed, and maintained. Here we find the never-ending struggles between the competitors, that is, the traditionalist, reformist/ modernist, the radicalist, and MUI. In the competition 'newcomers' like the reformist/ modernist in the early twentieth century and the radicalist in 1970s tried to promote and disseminate their orthodox characteristics and teachings in order to attract the following. Muhammadiyah in its early establishment until 1990s, for instance, was considered by majority as heterodox but now it has gained recognition from many segments of the Muslim society. It continues to increase its orthodox position through education, dakwah, and publication. In the beginning, the newcomers are considered as sect that tries to transform into the so-called denomination. A sect is recognized heterodox or heresy while denomination is orthodox. Such sects as Ahmadiyah and Islam Jamaah (Lembaga Dakwah Islam Indonesia, LDII) have made various attempts to gain recognition as orthodox denomination but it is not obtained until today. Recognized as heterodox sects, they are often forced to leave them and, rather, to return to adhere to the legitimate orthodox denominations.

Nevertheless, the relation between orthodoxy and heterodoxy is often relative and dialectic. In other words, "orthodoxy is not—as the orthodox would always have it—in singular possession of an invariable 'truth.' Rather, its contents are to be construed as

\footnotetext{
${ }^{35}$ Ibid.

${ }^{36}$ Yudi Latif, Indonesian Muslim, p. 454.
} 
fluid, as developing in a dialectic with heterodoxy." ${ }^{37}$ Heterodox at one time may become orthodox at another time. While certain types of authority recognize a religious stream as heterodox, others do it as orthodox. An interesting example is the position of Shi'ism in Indonesia. The orthodoxy of Shi'ism has been debated and contested. For radicalist groups such as Persatuan Islam (PERSIS), Dewan Dakwah Islam Indonesia (DDII), and Majlis Mujahidin Indonesia (MMI), Shi'ism is false and even disbelieving whereas, for Nahdlatul Ulama (NU) and Muhammadiyah, it is included within the Islamic orthodoxy though it is different from Sunnism. Similarly, in the eyes of MUI, Shi'ism is not considered as heterodox but MUI never issues a fatwa on Shi'ism except its 1984 recommendation to be wary of the spread and influence of Shi'i teachings. The recommendation shows the contrast between Sunnism and Shi'ism. Then it reads:

Considering the principal differences between Shi'ism and ahl al-sunna wa al-jama'ah as mentioned above especially regarding the difference on imamate (government), MUI appeals to the Indonesian Muslims who uphold ahl al-sunna wa al-jama'ah to increase awareness of the possibility of the coming of streams that are based on the teachings of Shi'ism. ${ }^{38}$

But the issuance of the recommendation is not free from political situations following the Iranian revolution and the establishment of Islamic Republic of Iran with its allegedly 'export of revolutionary ideas.' Mudzhar tried to explain the rationale for issuance of the recommendation by observing the socio-political development during early 1980s.

We know that 1979 was the year of the Iranian revolution, which toppled the secular government of the Shah and replaced it with an Islamic one. Apparently the echo of that resounded beyond Iranian territories and reached Indonesia. It was rumored that some Muslim youths were to be target of for the exportation of the ideas of the Iranian Islamic revolution. It was in this context that the government saw it necessary to take precautionary steps to prevent such Islamic revolutionary ideas from developing in the country, and it was also in this context that the MUI made it contribution to the efforts to preserve the establishment by issuing the fatwa. Thus, while the arguments of the fatwas were classical and theological in nature, the goals were contemporary and political. It is too obvious to ignore the fact that the actual concern of the fatwa was with the doctrine of the imama and nothing else. ${ }^{39}$

The Shi'is themselves continue to struggle to gain recognition as an orthodox Islamic denomination through various methods and strategies: dakwah, education, publishing,

\footnotetext{
${ }^{37}$ Jacques Berlinerblau "Toward a Sociology of Heresy, Orthodoxy, and Doxa," in History of Religions Vol. CLV No. 4, 2001, p. 332.

${ }^{38}$ A. Nazri Adlani et al. (ed.), Himpunan Fatwa Majelis Ulama Indonesia (Jakarta: MUI, 1997), p. 70.

${ }^{39} \mathrm{M}$. Atho Mudzhar, Fatwa of the Council of Indonesian Ulama: A Study of Islamic Legal Thought in Indonesia 1975-1988 (Jakarta: INIS, 1993) p. 115.
} 
and organization whilst the radicalists have made various efforts to promote the falsity of Shi'ism and to prohibit its existence in Indonesia. ${ }^{40}$ Although at the national level the position of Shi'ism is recognized as orthodox, at a certain local context it is seen as heterodox. The MUI of Sampang and of East Java has issued the fatwa of falsity of Shi'ism and this has been associated with the bloody sectarian violence in Sampang on 26 August 2012 in which one was killed, some wounded, and hundreds of Shi'is are taking shelter in the town's tennis indoor. Here with regard to Shi'ism competition occurs not only between Shi'is and anti-Shi'is but also between the national MUI maintaining the orthodoxy of Shi'ism and its local chapters struggling for its heterodoxy.

In contrast to Shi'ism, other minority currents have not yet gained recognition as orthodox denomination from other religious and state authorities. A case in point is the Ahmadiyyah. For all religious authorities such as NU, Muhammadiyah, and MUI, the Ahmadiyyah is deviant sect and, its adherents, particularly Qadiyanis, are not considered as Muslim. ${ }^{41}$ With regard to the position of Ahmadiyyah, "the issuance of the fatwa is more doctrinal than political in nature."42 Until now, the heterodox position of the Ahmadiyyah is firm, not debated among the existing authorities although the Ahmadis themselves continue their struggle to gain recognition. From this description, it is evident that the relation between orthodoxy and heterodoxy may be doctrinal or political.

Included in the domain of authority and orthodoxy is the violent action of radical groups that is strongly rejected by moderate mainstream within the Islamic society. Likewise, the ulama regard the radical groups as heterodox and to be marginalized. The action is popularly known as terrorism that refers to "acts that aim to instill terror within a community, particularly through the use of unexpected and shocking violence against non-combatants by clandestine groups or agents." ${ }^{43}$ Sometimes the heterodox radical group is characterized within the rubric salafi jihadism, that is, "a distinct substream within Salafism comprising those who believe that violent jihad is the only way to achieve their goals." ${ }^{44}$ But some ulama of the radical groups have tried to defend the violent action, protect the actors, and promote the brand of Islam as orthodox even though the legitimate religious and state authorities have condemned them and brought them to the court.

In addition to the problem of orthodoxy, recognition in the competitive religious field also takes place between the aspiring ulama or ustadz (religious teacher) as new entrants and the ulama. The new entrants exist in each of the Muslim groups (traditionalist, reformist, and radicalist). Varied attempts are made to accumulate capitals and transform them into symbolic capital in order to be recognized as the legitimate religious authority. In the

\footnotetext{
${ }^{40}$ Zulkifli, "The Struggle of the Shi'is in Indonesia" (Ph.D Thesis, Leiden University, 2009).

${ }^{41}$ Adlani, Himpunan Fatwa, p. 71.

${ }^{42}$ Mudzhar, Fatwa of the Council, p. 116.

${ }^{43}$ Fealy and Hooker, The Voices of Islam, p. 5.

${ }^{44}$ Ibid.
} 
reformasi era, Indonesian Islam has witnessed the emergence of numerous Muslim groups among the youth outside the existing Muslim organizations. Front Pembela Islam (FPI), Forum Ulama Umat Islam Indonesia (FUUI), and Majelis Intelektual dan Ulama Muda Indonesia (MIUMI) are among famous new entrants in the competitive religious authority in Indonesia in which they struggle to gain recognition in their own ways.

In the competitive religious field, attempts are made by each of them to obtain the most recognized position or the most legitimate orthodoxy. The ultimate goal of the struggle is gaining symbolic capital, which may be defined as "capital-in whatever form-insofar as it is represented i.e., apprehended symbolically, in a relationship of knowledge or, more precisely, of misrecognition and recognition, presupposes the intervention of habitus ${ }^{45}$, as a socially constituted cognitive capacity." ${ }^{46}$ It is a credit and "the power granted to those who have obtained sufficient recognition to be in a position to impose recognition." ${ }^{47}$ The symbolic capital that is the most sought after by these agents is the recognition of legitimate authority among all segments of the Muslim community in the country. The recognition as the legitimate authority is a kind of symbolic capital that is the most sought after by the competitors. Thus, the religious field is dynamic in that agents permanently maneuver in the competition for the symbolic capital. Bourdieu writes: "Symbolic capital is the product of a struggle in which each agent is both ruthless competitor and supreme judge.... This capital can only be defended by a permanent struggle...."48

The emerging concept for the type of capital is spiritual capital which may be understood as "the power, influence, knowledge, and dispositions created by participation in a particular religious tradition." ${ }^{49}$ With regard to Islam, Hefner includes in the concept of spiritual capital "features of faith-based organizations, including networks, norms, knowledge, and socialization that make possible the achievement of certain ends that would not be attainable in its [social capital's] absence...."50

The legitimate religious authority as a kind of symbolic or spiritual capital is the

${ }^{45}$ The notion of habitus can be understood as "a system of lasting, transposable dispositions which, integrating past experiences, functions at every moment as matrix of perceptions, appreciations, and actions and make possible the achievement of infinitely diversified tasks" (Bourdieu, 1977: 82-83).

${ }^{46}$ Pierre Bourdieu, "The Forms of Capital," in J.G. Richardson (ed.) Handbook of the Theory and Research for the Sociology of Education (New York: Greenwood Press, 1986), p. 255.

${ }^{47}$ Pierre Bourdieu, "Social Space and Symbolic Power," in Sociological Theory, Vol. VII No. 1, 1989, p. 23

${ }^{48}$ Pierre Bourdieu, The Logic of Practice, transl. Richard Nice (Stanford: Stanford University Press, 1990), p. 123.

${ }^{49}$ Peter L. Berger and Robert W. Hefner, "Spiritual capital in Comparative Perspective," (unpublished paper), p. 3.

${ }^{50}$ Robert W. Hefner, "Islam and Spiritual Capital: An Indonesian Case Study" in Peter L. Berger and S.G. Redding (ed.), The Hidden Form of Capital: Spiritual Influences in Societal Progress (Anthem: Anthem Press, 2010), p. 194. 
foundation for the ulama to have symbolic power. In other words, the symbolic capital becomes a credit to gain the legitimate religious authority in the struggle. "Symbolic power is a power of consecration or revelation, the power to consecrate or to reveal things that are already there." ${ }^{51}$ It is also defined as: "power to constitute the given by stating it, to show forth and gain credence, to confirm or transform the worldview and, through it, action on the world, and hence the world itself, quasi-magical power which makes it possible to obtain the equivalent of what is obtained by (physical or economic) force, thanks to its specific mobilization. ${ }^{52}$ In accordance with Bourdieu's view, in order to have symbolic power, ulama have to meet two conditions: first, the possession of symbolic capital and second the symbolic efficacy of the vision proposed. Although ulama may gain recognition as legitimate religious authority, they will be considered to have symbolic power only when the effect of the recognition is proven or when their followers strictly follow their teachings, commands, or fatwa. Thus, the symbolic power of ulama exists only in the relationship between the ulama exercising the power and their followers submitting to it namely in the structure of religious field in which religious authority is produced and reproduced.

In addition to the symbolic power which is exercised based on recognition or legitimacy from the complicity of those who submit to it, it is also the invisible power which depends on misrecognition by concealing particular interest into legitimate interest or disinterest. Those who misrecognize the particular interest like private or economic interest then recognize the legitimacy and authority of the ulama.

The symbolic power is obtained by implementing various kinds of strategy in the maneuvers. For Bourdieu, "the idea of strategy, as a way of directing practice that is neither conscious and calculated nor mechanically determined, but is the product of the sense of honour as a feel for that particular game, game of the honour." 53 As a feel for game, the concept of strategy is neither freewill nor predestination. It is interesting to note that it is similar to Ash'arite theology of human action in that it exists in between freewill and predestination. It includes the strategy of reproduction and reconversion. The strategy of reproduction includes all acts designed to maintain and improve position while the strategy of reconversion is the transferring of accumulated capitals into another type. The concept of strategy also conceals any kinds of interest that are made disinterest. Bourdieu considers symbolic capital as the product of a kind of social alchemy, that is, a process of misrecognition in which the real interest is concealed. Misrecognition is a denial of the real interest. ${ }^{54}$ Thus, the ulama with symbolic power possess the legitimate religious authority

\footnotetext{
${ }^{51}$ Pierre Bourdieu, "Social Space," p. 23

${ }^{52}$ Pierre Bourdieu, "Symbolic Power," in Critique of Anthropology No. IV, 1979, p. 82-83.

${ }^{53}$ Bourdieu, The Logic of Practice, p. 22.

${ }^{54}$ Ibid, p. 129.
} 
and recognition that are to be maintained and reproduced. It is the symbolic power that imposes the exercise of legitimate religious authority and recognition.

\section{Conclusions}

The fragmentation of religious authority in Indonesia is an endless phenomenon and with global media and information technologies religious authority becomes more pluralized. In this context, the complex struggle and competition among the ulama of certain Muslim groups and the new entrants in the competitive religious field to gain legitimate religious authority, recognition, symbolic capital, and symbolic power is an unending process. The religious authority does not function effectively without symbolic power; the ulama are not obeyed without holding symbolic power. Conservation (reproduction) and succession always mark maneuvers of each group in the field, not only between the orthodox and the heterodox but also among the orthodox themselves. Thus, religious field is social and political and it is both worldly and godly matter.

\section{References}

Abdullah, Taufik. "The Formation of A New Paradigm? A Sketch on Contemporary Islamic Discourse" in Mark Woodward (ed.) Toward A New Paradigm: recent Developments in Indonesia Islamic Thought, Tempe, Arizona: Arizona University Program for Southeast Asian Studies, 1996.

Adlani, A. Nazri et al. (ed.), Himpunan Fatwa Majelis Ulama Indonesia. Jakarta: MUI, 1997.

Azra, Azyumardi, Jaringan Ulama Timur Tengah dan Kepulauan Nusantara Abad XVII dan XVIII: Melacak Akar-akar Historis Pemikiran Islam di Indonesia. Bandung: Mizan, 1994.

Azra, Azyumardi, Islam in the Indonesian World: An Account of Institutional Formation. Bandung: Mizan, 2006.

Badawi, Syansuri “Tarekat, Suatu Keniscayaan” in Pesantren Vol. II No.3, 1985.

Berlinerblau, Jacques. "Toward A Sociology of Heresy, Orthodoxy, and Doxa” History of Religions, Vol. CLV, No. 4, 2001.

Bourdieu, Pierre. Outline of a Theory of Practice. Translated by Richard Nice, Cambridge: Cambridge University Press, 1977.

Bourdieu, Pierre, "Symbolic Power" in Critique of Anthropology no. 4, 1979:77-85

Bourdieu, Pierre. "The Forms of Capital" in John G. Richardson (ed.) Handbook of the Theory and Research for the Sociology of Education, New York: Greenwood Press, 1986: 241-258.

Bourdieu, Pierre. "Social Space and Symbolic Power," in Sociological Theory, vol. 7 No. 1, 1989. 
Bourdieu, Pierre. The Logic of Practice. Translated by Richard Nice, Stanford: Stanford University Press, 1990.

Bourdieu, Pierre. "Genesis and Structure of the Religious Field," in Comparative Social Research No. 13, 1990.

Bourdieu, Pierre and Loic J.D. Wacquant. An Invitation to Reflective Sociology, Chicago: Chicago University Press, 1992.

Burhanudin, Jajat. "Islamic Knowledge, Authority, and Political Power: The 'Ulama in Colonial Indonesia." Ph.D Thesis, Leiden University, Leiden, the Netherlands, 2007.

Dhofier, Zamakhsyari. Tradisi Pesantren: Studi tentang Pandangan Hidup Kiai. Jakarta: LP3ES, 1982.

Dirdjosanjoto, Pradjarta. Memelihara Umat: Kiai Pesantren-Kiai Langgar di Jawa. Yogyakarta: LKiS, 1999.

Eickelman, Dale and J.W. Anderson. "Print, Islam, and the Prospects for Civic Pluralism: The New Religious Writings and Their Audiences" in Journal of Islamic Studies, Vol. VIII, no. 1, 1997.

Fealy, Greg and Virginia Hooker (ed.). Voices of Islam in Southeast Asia: A Contemporary Sourcebook. Singapore: ISEAS, 2006.

Geertz, Clifford. "The Javanese Kijai: The Changing Role of a Cultural Broker" Comparative Studies in Society and History, No. 2, 1959-1960.

Gellner, Ernest. Muslim Society, Cambridge: Cambridge University Press, 1983.

Hefner, Robert W. "Islam and Spiritual Capital: An Indonesian Case Study" in Peter L. Berger and S.G. Redding (ed.), The Hidden Form of Capital: Spiritual Influences in Societal Progress. Anthem: Anthem Press, 2010.

Horikoshi, Hiroko. Kiai dan Perubahan Sosial. Translated by Umar Basalim and Andi Muarly Sanrawa. Jakarta: P3M, 1987.

Humphreys, Stephen. Islamic History: A Framework for Inquiry. London: I.B. Thauris, 1999.

Latif, Yudi. Indonesian Muslim Intelligentsia and Power. Singapore: ISEAS, 2008.

Mansurnoor, Iik Arifin. "Ulama, Villagers, and Change: Islam in Central Madura" Ph.D Dissertasion, Institute of Islamic Studies, McGill University, Montreal, Canada, 1987.

Miller, Elmer S. and Charles A. Weitz. Introduction to Anthropology. Eglewood Cliffs: PrenticeHall, Inc., 1979

Mudzhar, M. Atho. Fatwa of the Council of Indonesian Ulama: A Study of Islamic Legal Thought in Indonesia 1975-1988. Jakarta: INIS, 1993.

Nicholson, R.A. The Mystic of Islam. London: Routledge and Kegan Paul lit., 1975.

Turmudi, Endang. Perselingkuhan Kiai dan Kekuasaan. Yogyakarta: LKiS, 2003.

Turner, Bryan S. "Religious Authority and the New Media," in Theory, Culture, and Society, Vol. XXIV No. 2, 2007. 
Weber, Max. Theory of Social and Economic Organization. Translated by A. Henderson dan Talcott Parsons. Glancoe-Ill: The Free Press, 1957.

Zaman, M. Qasim. The Ulama in Contemporary Islam: Custodians of Change. Princeton: Princeton University Press, 2001.

Zulkifli. "The Struggle of the Shi'is in Indonesia" Ph.D Thesis, Leiden University, Leiden, the Netherlands, 2009. 